\title{
Славянская буква
}

Коптелов Вячеслав Олегович - ученик 6 класса.

Толкачев Сергей Витальевич - ученик 6 класса. Город Тобольск Тюменская область МАОУ СОШ № 17. Введение

С образованием государства на Руси резко возникла необходимость в развитии письменности: заключение договоров, издание законов, указов, налоговая система, богослужение и т.д.

Мировоззрение, взгляды на жизнь отражались в устной, а позже в письменной речи. Смысл слова приходил к человеку через смысл каждой буквы.

Славянская буква - уникальное явление среди всех известных способов буквенного письма. Она отличается от других алфавитов принципом однозначности графического изображения: один звук - одна буква, которая построена на основе линии. Каждое слово фразы начинается с той же буквы, которой заканчивается предыдущая фраза.

Цель исследования: изучение написания буквы славянской азбуки через линию.

Материал исследования: линия - основа славянской письменности.

Методы исследования:

1. Поиск информации и создание исследовательской работы.

2. Анализ и синтез данных, полученных при изучении научных источников.

3. Изучение собранного материала и обобщение данных.

До реформы языка 1918 года каждая буква азбуки имела своё название. Каждая буква стояла на своём месте. Русская азбука - это не только набор букв, соответствующих звукам, это ещё и целое послание к славянам. Три первые буквы азбуки - Аз, Буки, Веде. Азъ буки веде - Я знаю буквы.

Основная часть

Буква - это единица, это символ мысли. Буквы имеют определённую форму, графику написания. За каждой буквой стоит своя цифра, своё число. Ещё Пифагор утверждал, что у буквы и цифры одинаковые вибрации, то есть буква 
содержит в себе определенную информацию. В последнее время группа российский учёных (Г.С. Гриневич, Л.И. Сотникова, А.Д. Плешанов и другие) доказали, что в нашей Азбуке в зашифрованном виде содержатся знания о законах мироздания. Каждая буква русской Азбуки является символом чеголибо. Буква «Ж» — это символ жизни. Она означает соединение мужского и
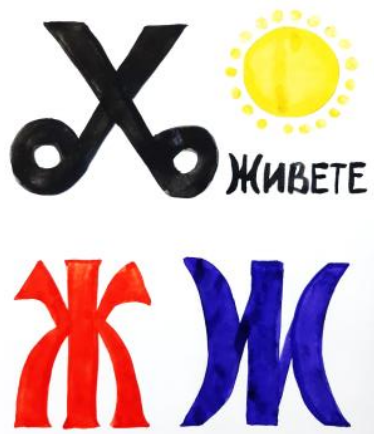
женского начал. И название она имела соответствующее «Живёте». То есть за каждой буквой у наших предков были определённые образы, передаваемые через линию.

Рис. 1. Линия-основа символа и буквьл.

Большое значение у наших предков имел символ. Он нёс в себе основную смысловую нагрузку в магическом и жреческом искусстве. Символ (греч.) - это отличительный знак, образ, воплощающий какую-либо идею. Смысл символа должен быть понятным людям, принадлежащих к этой группе, т.е. для тех, кто не посвящен в значение символов он остается тайным или условным знаком. Повседневная жизнь человека наполнена символами, которые напоминают и воздействуют, разрешают и запрещают, поражают и покоряют. Образ женщины - как символ плодородия земли, тайны жизни и мира, мужчина - как символ решительности.

Славянские символы - это сложная многоуровневая система, которая охватывает разные стороны жизни. В основе знаков-символов лежит линия.

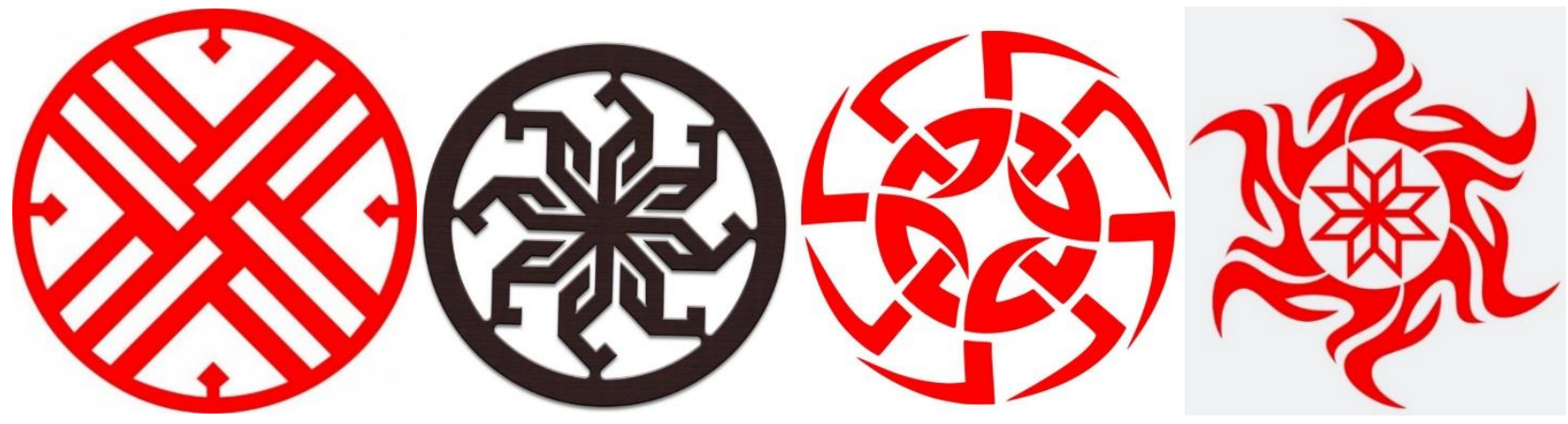

Рис. 2. Славянские символьи Солнщуа.

Через нее славяне передавали строение Вселенной, нашей Галактики, Млечного Пути. Знаковая линия прежде всего посвящена защите - семей, родов, жилища, 
детей, женщин, воинов, знаний и мудростей. Через них отражали разрушительные силы, на бытовом уровне они служили оберегом.

Линия могла образовывать круг, квадрат, ромб, треугольник. Её можно видеть прямой, волнистой, ломанной, длинной и короткой. Через линию славяне передавали свои знания в вышивке и декоре народной одежды, наличниках окон, в убранстве предметов быта. Графическое строение каждого знака - буквы считывается, донося до нас заложенную информацию.

Говорить, что азбуки у славян до 863 года (год славянской письменности) не было неверно. Рунических книг древних славян не найдено, письменность у славян встречается на могильных камнях, берестяных свитках и оружии. На пергаментных рукописях (кожа специальной выделки), дошедших до нас, мы видим, что текст, нанесенный первоначально, был соскоблен, а другой наложен сверху. В те времена часто прибегали к такому приему, потому что обработка кожи была не легким занятием. Текст, который был соскоблен, написан глаголицей. Текст же, который нанесен сверху, являлся кириллицей. И до сегодняшнего дня не нашли ни одного пергамента, где глаголица была бы нанесена поверх кириллицы. Самый древний славянский текст, дошедший до нас, написан глаголицей. Имеется много свидетельств, датируемых разными веками, и в них говорится, что славяне имели письменность и счет еще в языческие времена. [Гриневич Г.С. Праславянская письменность. Результаты дешифровки. Том 1. М., «Общественная польза». 1993. с. 3-4. Сотникова Л.И. Истинная азбука русского языка. М. Элиста. 1999. с. 1-2].

Слово руна или руны происходит от англо-саксонского слова, которое обозначает «секрет» или «тайна». Каждая руна обозначала не звук, а слог, а это мешало написанию книг, писем, документов. Поэтому, когда пошло распространение христианства, славянам, были необходимы книги на своем языке для понимания и принятия истинной христианской веры. [Платов А.В., Таранов Н.Н. Руны славян и глаголица. М. ООО «Издательский дом «Вече», 2010]. 
В те времена чтение проповедей допускалось на трех языках - латыни, греческом и иврите. Кирилл и Мефодий составили славянскую азбуку и занялись переводом священных книг на славянский язык.

Князь Ростислав, всю жизнь боровшийся за независимость Моравии от немцев, не хотел влияния католической церкви. Потому просил византийского правителя Михаила III «прислать в Великую Моравию епископа и учителя, дабы он на языке нашем изложил правую христианскую веру». Кирилл с радостью согласился, так как считал, что «просвещение народа без письмен языка его подобно попыткам писать на воде». [Бурега В. Святой Ростислав князь Моравский. Православие.ru. c.1-4.].

У каждой из букв кириллицы есть свое название, и, если прочесть эти названия в порядке алфавита, получится: «Азъ буки веде. Глаголь добро есте. Живите зело, земля, и, иже како люди, мыслите нашъ онъ покои. Рцы слово твердо - укъ фърътъ херъ. Цы, черве, шта ъра юсъ яти». Что в переводе означает: «Я знаю буквы: письмо - это достояние. Трудитесь усердно, земляне, как подобает разумным людям - постигайте мироздание! Несите слово убеждённо: знание - дар Божий! Дерзайте, вникайте, чтобы сущего свет постичь!».

Есть теория, что глаголица создана на основе славянских рун и, хотя прямых исторических доказательств этому нет, она имеет право на существование. [Платов А.В., Таранов Н.Н. Руны славян и глаголица. М. ООО «Издательский

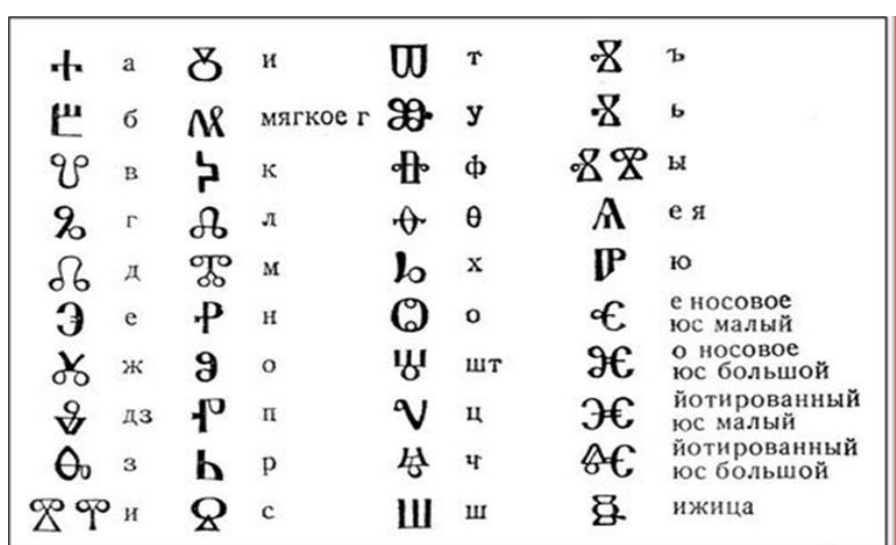
дом «Вече», 2010. с.7.].

Азбука глаголицы имеет 43 буквы, которые несут в себе цифровое значение, название и собственные имена. В глаголице буквенные обозначения более Рис. 3. Глаголищяа.

сложны в написании: имеют округлую форму и множество завитков. В основе форм лежит круг - символ бесконечности, символ Солнца и треугольник символ мудрости. 
Славянская азбука - явление совершенно уникальное, в ней есть буквы, звуки и содержание. При обозначении чисел в календаре славяне использовали буквы, а не цифры. Из этого следует, что письменность на Руси существовала более семи тысяч лет. Кирилл и Мефодий убрали из Буквицы непонятные для них буквы, а часть букв заменили на греческие. Соответственно смысл образов был искажён. Так появилась Азбука-Кириллица. Сейчас мы пользуемся только алфавитом. В алфавите буквы - это просто значки, написанные с помощью линии, они не вызывают ассоциаций, не имеют смысла и значения. В Буквице каждая буква - это образ или действие.

То есть образ возникает не только от слова, за каждой буквой стоит конкретное описание явления или действия. Первая буква пишется - А, читается - А3, обозначает - Я. А Б В - Азъ Боги Веди - Я Бога Ведаю, Знаю. Г Д - Глаголь Добро - говори, делай добро.

Д Е Ж - Добро Есть (это Жизнь).

Слова слагали из букв, каждая из них писалась через линию. В таких буквах как о, а, б, в, д, p, с, ф, ы, э, ю, я - в основе лежит круг или овал - символ Солнца, символ бесконечности рода человеческого, символ знаний, мудрости, символ славянской письменности, написанный через графическое изображение линии. При написании слова через графическое изображение буквы, имеющие определенный смысл, каждое слово имеет глубокое значение. Правильное понимание смысла буквы дает ключ к расшифровке любого слова.

\section{Результаты исследования}

Рассматривая древние славянские символы как геометрические фигуры, можно заметить, что простые линии сплетаются в рисунок, состоящий из круга, овала, квадрата, треугольника. В основе славянской азбуки лежит линия: замкнутая, прерывистая. В письменности буквы как символы не были 
обособленны друг от друга, они имели общие черты. Каждый знак - буква был частью общего и дополнял целостную картину алфавита.

В большинстве славянской азбуки лежит круг символ Солнца, солярный знак Солневорота, который напоминает вращающую галактику.

В глаголице, в каждом знаке присутствует цифровое значение и название, которое создает образ. Но разница в том, что в глаголице «аз» соответствует единице,

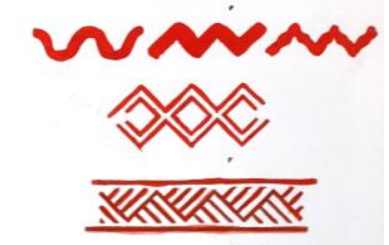
«буки» - двойке и так далее. В кириллице цифры привязаны к числовым значениям соответствующих букв греческого алфавита. Поэтому «аз» - единица, а «веди» - двойка. Есть и другие несовпадения.

Кириллица оказалась наиболее удачной версией азбуки и существует в наше время. На её основе пишут более 70 народов славянской группы. В наше время кириллица имеет 33 буквы, и называется она алфавит. Такой вид она приобрела в 1918 году, после реформы.

Глаголица - не исторически сложившийся, а искусственный алфавит для церковного письма.

Кириллица - историческая основа современных алфавитов практически всех православных славянских народов. Это Устав - Полуустав - Вязь (с X до XVIII вв.). Кириллица плавно вписалась и в старославянский алфавит.

Буква - это единица, это атом смысла. Буквы - это магические символы, которыми пользовались славяне в дохристианскую эпоху. Буквы складываются в слова. А каждое слово - это любовь, добро, жизнь, написанное через графическое изображение буквы - символ - линия.

Рассмотрев и изучив буквы славянской азбуки, мы пришли к выводу, что графическое изображение букв состоит из простых линий, расположенных вертикально, горизонтально, наклонно, образуя геометрические фигуры, буквы просты, красивы, удобны, понятны и ясные в написании и произношении, в отличие от латинских и греческих. 
Азбука в своем графическом исполнении поставила письменность на высокий уровень в мировой истории развития письма. При помощи азбуки было проведено математическое образование славян: буквы азбуки выражали соответствующие числа.

Практически, был создан новый язык - славянский, основанный на графической линии. В обращение было введено огромное количество слов, отсутствовавших в живых наречиях. Они образовали новые значения, которые отражали уровень новой культуры и духовного содержания, которое пришло с переводом религиозной литературы. Язык был зафиксирован при помощи славянской письменности.

Изучив азбуку с самых «азов», мы видим, что Кирилл и Мефодий оставили своим потомкам главную ценность - творение, которое призывает нас стремиться к самосовершенствованию, учению, мудрости и любви.

Надеемся, что наша работа послужит примером для наших сверстников изучать прошлое своего народа, с чего всё начиналось и как всё развивалось. Пока мы знаем, помним - история нашего народа будет сохранена.

Наша работа содержит исторический материал, который можно использовать на уроках истории, изобразительного искусства, классных часах и в других исследовательских работах.

\section{Заключение}

Азбука нам дана как дар, как послание через века о том, что жить людям нужно по совести, в труде, оказывать помощь ближнему. На сегодняшний день, приблизительно 6\% населения мира считают кириллицу своим языком. Дети, идущие в школу, начинают познавать мир, с изучения языка на котором говорили их предки. Это формирует их, как личность и дает чувство причастности к славянской культуре и письменности. Читающий народ считался грамотным. Роль Кирилла и его брата Мефодия является основной в развитии языка и письменности. Но огромна их заслуга и в том, что оставили после себя учеников, которые продолжили их дело. 
Славянская азбука - уникальное явление среди всех известных способов буквенного письма. Она отличается от других алфавитов не только совершенным воплощением принципа однозначности графического отображения (один звук - одна буква), но и линией в начертании букв, которая играет значимую роль. От «черт и резов» в дохристианской письменности к правильной линии в славянской азбуке. [4. Гриневич письменность. Результаты дешифровки. Том 1. М., «Общественная польза». 1993. c. 3-4.].

Сравнивая множество находок, исследователи пришли к выводу, что первая славянская азбука была создана как целостное изобретение, а не как творение, которое создавалось по частям путем добавления новых буквенных форм. [Бычков А.А., Громов Д.В. Славянские руны: факты и домыслы. М., 2005. Велинский С.Г., Сказание Черноризца Храбра. «О письменах славянских». Одесса. «Экономическая типография, Почтовая улица, дом 43. 1901. Платов А.В., Таранов Н.Н. Руны славян и глаголица. М. ООО «Издательский дом «Вече», 2010.].

\section{Список литературы:}

1. Бурега В. Святой Ростислав князь Моравский. Православие.ru. c.1-2.

2. Бычков А.А., Громов Д.В. Славянские руны: факты и домыслы. М., 2005. c 7 .

3. Велинский С.Г., Сказание Черноризца Храбра. «О письменах славянских». Одесса. «Экономическая типография, Почтовая улица, дом 43. 1901.

4. Гриневич Г.С. Праславянская письменность. Результаты дешифровки. Том 1. М., «Общественная польза». 1993. с. 3-4.

5. Платов А.В., Таранов Н.Н. Руны славян и глаголица. М. ООО «Издательский дом «Вече», 2010. с.7.

6. Сотникова Л.И. Истинная азбука русского языка. М. Элиста. 1999. с. 1-2 